\title{
State Formation in First Millennium Southeast Asia: A Reappraisal ${ }^{*}$
}

\author{
Anton O. Zakharov \\ Institute of Oriental Studies, Moscow; \\ Moscow State University of Psychology and Education
}

\begin{abstract}
The paper analyses the characteristic features of the emerging 'Indianized', or 'Indic' kingdoms in Southeast Asia. The paper traces the connections between the power structures and various forms of violence, including warfare. The main sources are inscriptions in Sanskrit, Old Malay, Old Javanese, and Old Khmer. State formation is viewed as the formation of power structures, institutions, and arrangements. Contrary to current scholarly convention stated by Michael Vickery and Dougald O'Reilly that the decisive step to territorial states in Southeast Asia is the origin of the Angkor Empire in 802, the author supposes that the seventh century was crucial for the formation of the territorial polities. The inscriptions of the seventh century issued by the kings of Srivijaya, Chenla (Zhenla), and Campā, do mention territorial units inside the whole kingdom.
\end{abstract}

\section{INTRODUCTION}

Since more than twenty years after the seminal state-of-the-art review by Jan Wisseman Christi (1995) on state formation in Insular Southeast Asia, the regional state formation has been viewed from several theoretical perspectives. The first perspective tends to emphasize local features of the local polities that existed in the first millennium before the emergence of the Angkor Empire in 802 in Mainland Southeast Asia. The proponents of this approach are the late Michael Vickery (1998) and Dougald O'Reilly (2007). The scholars deny the applicability of the term 'state' to local political entities. Vickery offers the concept of poñ-ship as a designation of a complex political system where the main role was played by the local 'chiefs' - poñ, who are

Social Evolution \& History, Vol. 18, No. 1, March 2019 217-240

(C) 2019 'Uchitel' Publishing House

DOI: $10.30884 / \mathrm{seh} / 2019.01 .12$ 
often mentioned in the Old Khmer Pre-Angkorean inscriptions. Vickery tries to avoid even the term 'chief' as resembling other forms of political organization such as tribes or chiefdoms. But the term 'poñship' is coined as kingship or lordship, and has sense if one bears in mind its connections with a kind of authority and power only.

O'Reilly defines as chiefdoms the political entities of Indochina before Angkor. Vickery and O'Reilly follow Oliver Wolters' ideas of local genius and individuality of Southeast Asian societies (Wolters 1982, 1999; cf. Acri et al. 2016). They share Wolters' statement that the Indic or Chinese models of statehood are inapplicable to Southeast Asian polities, contrary to the early scholars of Southeast Asia like George Cœdès (1968) and Ramesh Chandra Majumdar (1927, 1937) who emphasized the great influence of India and, to a lesser degree, of China on Southeast Asian countries.

The second perspective follows other Wolters' idea of mandala (Sanskrit 'a circle of kings') as a distinct system of local polities' relations with an unstable position of the hegemonic polity. The concept of mandala as a description of the four-level settlement hierarchy which presumably reflects a certain political system is advocated by Stephen Murphy $(2010,2012)$.

Some scholars also consider the early Southeast Asian polities as city-states (Manguin 2000) or port-polity (Kathirithamby-Wells 1990). Pierre-Yves Manguin (2002) argues for the 'amorphous nature' of maritime polities of Insular Southeast Asia. He stresses that 'the state is a process' (Manguin, personal communication). But I would say the process is a sequence of changes of various states/conditions, and of states of changes.

Kenneth Hall (2011) in his textbook on early Southeast Asian history emphasizes the leading role of trade in political formation of complex societies. The collective monograph edited by Ian Glover and Peter Bellwood Southeast Asia: From Prehistory to History shows the usage of neutral terms 'polity', 'kingdom', and 'empire' as descriptions of various political entities of early Southeast Asia (Glover and Bellwood 2004). Still, William Southworth (2004) did name his chapter 'The Coastal states of Champa'. Miriam Stark (2004) dates the transition to history to the beginning of the Common Era when the first complex literary societies appeared in the Lower Mekong Delta. Codès treated these societies as the states (1944, 1948, and 1968). Wisseman Christie asserted that the first states in Island Southeast Asia 
did emerge in the third century BCE but there is no data in favour of such statement.

Therefore, there is no scholarly agreement concerning the nature of the early Southeast Asian polities, the regional state formation, and, to a lesser degree, its causes. I would formulate few theses that help to place Southeast Asia in the world historical and evolutionary perspective. First, Southeast Asia is in no way a region of primary state formation, pace any interpretation of the nature of the state as a type of political organization. The first states emerged outside Southeast Asia; therefore the Southeast Asian polities belong to the kinds of secondary state formation. Second, Southeast Asian societies have been influenced by other regions and societies throughout its history. Some Southeast Asian societies influenced other Southeast Asian societies as well. Thus, one can trace multiple processes of foreign and intraregional influence. Third, I will focus on state formation in the regions of Indianized, or Indic kingdoms because I can read their inscriptions which are written in Sanskrit and in vernacular languages in Indic scripts and with strong lexical Sanskrit input; the role of 'Sanskrit Cospomolis' in South and Southeast Asia was discussed by Sheldon Pollock (2006) in detail.

In Southeast Indochina, complex polities with social and settlement hierarchies, literary cultures and specialized governments emerged in the first centuries CE. Their birth coincides with the growth of world trading system which included the Roman Empire, the Parthian Empire, the Kushan Empire, and the Han Empire. The growth of trade networks and flows between East Asia and South Asia with the mediating role of the inhabitants of Southeast Asia seemingly promoted the struggle for the access to, and control over, international trade roots. This struggle was conducive for the constructions of local complex polities (Hall 1985). Straight navigation from Hindustan to Nanhao and Guanzhou became possible from the fourth century onwards, i.e., it dates later than the first complex polities of Southeast Asia do.

\section{THE KINGDOM OF FUNAN}

Since the first century CE, the Oc Eo culture in the Lower Mekong Delta reveals the multi-tiered settlement system. The artefacts of this culture include inscriptions on seals and intaglios in Indic script and golden plaques depicting various Hindu deities (Malleret 1960-1963; Le Thi Lien 2005). The aerial photography by the French scholar Pierre Paris has shown a system of ancient canals which were later 
examined by the French archaeologists. The canal connecting the site of Oc Eo with the ancient settlement Angkor Borei was 90 kilometers long (Higham 2002: 237; cf. Manguin 2004: 291). French, Vietnamese and American archaeologists also found temples and ancient wooden sculptures, for example wooden Buddha statues dating from 300600 CE (Vo Si Khai 2003: 65, 85; Tingley 2009: 126).

The Chinese sources date the emergence of the kingdom of Funan 持南 to the first century CE (Pelliot 1903). Funan was located in the Lower Mekong Delta. The kingdom of Linyi 林邑 situated in the region of the modern city of Huế dates from $192 \mathrm{CE}$, according to the Chinese and Vietnamese written sources (Stein 1947). These data correlate with the recent archaeological findings and reflect the changes in political systems of Southeast Indochina.

The fourth and fifth centuries give the first examples of royal inscriptions in Southeast Indochina and in the Indonesian Archipelago. The royal inscriptions in Sanskrit praise the local kings. Only in the sixth and seventh centuries, royal inscriptions started to use vernacular languages. From the sixth sentury onwards the kingdom of Bhava or Zhenla 槙巤in Chinese sources, located in modern Cambodia, began to use Old Khmer. In the late seventh century the kingdom of Srivijaya located in Sumatra used the Old Malay language. ${ }^{1}$ All these early texts are engraved by the Indic script 'Pallava'. The earliest dated royal inscriptions of Java belong to the eighth century. During the late eighth century, the Javanese monarchs also made use of another Indic script 'Nagarî' for the Buddhist texts. In 802, Jayavarman II founded the Angkor Empire which, according to a number of scholars, marks the beginning of the new historical epoch in the history of Indochina or, even of the whole Southeast Asia (Cœdès 1968; O'Reilly 2007; Hall 2011; Vickery 1998).

The earliest examples of royal inscriptions in the Indonesian Archipelago are the records of the King Mūlavarman engraved on the sacrificial posts in the Mahakam River Valley on South East Borneo (Vogel 1918; Chhabra 1935, 1965). The inscriptions of the King Pūrnavarman found in the region of modern Jakarta in West Java are slightly later (Vogel 1925) (Fig. 1). 


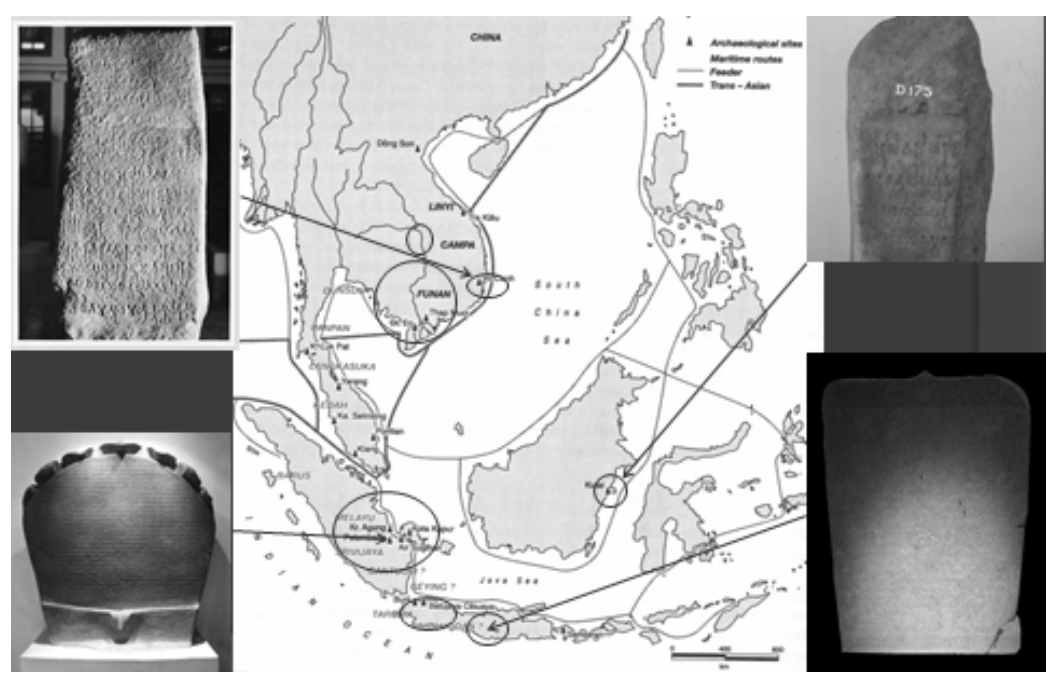

Fig. 1. The localization of early royal epigraphy in Southeast Asia

According to Leonid Grinin,

The early state is a category by means of which we denote a specific form of political organization of a sufficiently large and complex craft-agrarian society (or a group of such societies/territories) that controls its external policy and, partly, social order; at the same time this political form is a power organization separated from the population, which a) possesses sovereignty (or, at least, autonomy); b) is capable of forcing the population to fulfill its demands, change important relationships and introduce new ones, and redistribute resources; and c) is not built (basically, or mainly) on kinship principles (Grinin 2008: 78).

The descriptions of Funan in the Chinese sources may evidence that Funan was an early state according to Grinin's definition. 'Jin Shu' 晉書, 'History of the Kingdom of Jin', telling about the events from 265 to 419, but composed in the late sixth - early seventh centuries by Fang Xuanlin, says

There are walled cities, palaces and dwellings... They devote themselves to agriculture. They sow one year and harvest for three. ${ }^{2}$ Moreover, they like to engrave ornaments and to chisel. Many of their eating utensils are silver. Taxes are paid in gold, silver, pearls, and perfumes. There are books and depositories of archives and other things. Their 
characters for writing resemble those of the $\mathrm{Hu}$ [a people of Central Asia using a script of Indian origin] (Coedès 1968: 42, quotation from Pelliot 1903: 254). ${ }^{3}$

'Nan Qi Shu' 南齊書, 'History of the Southern Qi', written by Xiao Zixian in the early sixth century, which tells about 479-501 CE, says:

The people of Funan are malicious and cunning. They take by force the inhabitants of the neighbouring cities who do not render them homage, and make them slaves. As merchandise, they have gold, silver, silks... The people of Funan make rings and bracelets of gold and vessels of silver. They cut down trees to build their houses. The King lives in a storied pavilion. They make their enclosures of wooden palisades... The people also live in houses raised from the ground. They make boats 80 or 90 feet long abd 6 or 7 feet wide... (Yung 2000: 13; Coe 2003: 58; cf. Pelliot 1903, 261; Cœdès 1968: 58).

'Liang Shu' 梁書, 'History of the dynasty of Liang', composed by Yao Silian in the first half of the seventh century, and focusing on the years 502-556, says that 'the country produces gold, silver, copper, tin, aloe perfume, ivory...' (Pelliot 1903, 263) and

Where they live, they do not dig wells. By tens of families, they have a basin in common where they get water. The custom is to adore the spirits of the sky. Of these spirits, they make images in bronze; those which have two faces, have four arms; those which have four faces, have eight arms. Each hand holds something - a child, a bird, or quadruped, the sun, the moon. The King, when he travels rides an elephant. So do his concubines, the people of the palace (Yung 2000: 14; Coe 2003: 58-9).

Embassies from Funan arrived to Chinese courts between 226231 and $243-244$, in $268,285,286,287,357,434,435,438,484,503$, $511,512,514,517,519,520,530,535,539,559,572,588$, and in the period between 618 and $649 \mathrm{CE}$ (Wheatley 1983: 153).

Therefore, according to the Chinese sources, Funan was a country with cities and considerable labour division. For example, there were agriculture, crafts, and long-distance trade. The kings of Funan used methods of taxation. Their subjects built ships. The kings raided elephants not later than the fifth century. The multi-faced and multiarmed images of deities suppose the Indian influence. According to 'History of Southern Qi' and 'History of the dynasty of Liang' Funan people knew writing because in 484, the king Qiáochénrú Shéyébámó 僑陳如闍耶跋摩 (Kauṇ̣inya Jayavarman) sent a written request to 
the Chinese court with the Buddhist monk Nàqiéxiān/Nāgasena 那伽仙 (Pelliot 1903: 257-60, 269). All these data allow us to consider Funan as an early state.

\section{ROYAL EPIGRAPHY AND WARFARE}

All royal inscriptions of Southeast Asia are evidence that they were left by complex political systems of the early state type. These inscriptions also shed some light on the factors of secondary state formation in addition to trade and exchange. The epigraphy shows the significance of wars and conquests, at least, in the ideologies of early states. Table 1 brings together epigraphic evidence of wars, battles, conquests, and victories in early Southeast Asia.

Table 1

Wars in early royal inscriptions of Southeast Asia

\begin{tabular}{|c|c|}
\hline Kingdom/area/king/date & Inscriptional Evidence \\
\hline $\begin{array}{l}\text { Vo-canh, Nha Trang, Cen- } \\
\text { tral Vietnam, the fourth- } \\
\text { fifth centuries }\end{array}$ & $\begin{array}{l}\text { prathamavijayāya 'for the first victory', line } 7 \text { of } \\
\text { the Vo-canh inscription C. } 40^{4}\end{array}$ \\
\hline $\begin{array}{l}\text { Funan, Lower Mekong } \\
\text { Delta, Gunavarman, } \\
\text { the fifth-sixth centuries }\end{array}$ & $\begin{array}{l}\text { yudhi vīra...nāmnā narädhipatinā saha yu... 'in the } \\
\text { battle [where] the king Vīra [participated] along } \\
\text { with...'; ripugañās 'armies of the enemies'; } \\
\text { nirdagdhārāma 'the burned garden'; jambāt- } \\
\text { tabhojakapade 'the abode of priests conquered in } \\
\text { the mud', the inscription Pràsàt Prằm Lovên or } \\
\text { Tháp-mười K. } 5\end{array}$ \\
\hline $\begin{array}{l}\text { Vat Phou (Laos), Devā- } \\
\text { nīka, the fifth-sixth centu- } \\
\text { ries }\end{array}$ & $\begin{array}{l}\text { dhanañjaya iva ripuganavijaye '[who] defeats } \\
\text { enemy troops like Dhanañjaya (Arjuna)'; dvișada- } \\
\text { nekānikkāvāptavijayo vijaya iva '[who] manage to } \\
\text { gain victory over many troops of enemies like Vi- } \\
\text { jaya (Arjuna) did', lines } 8 \text { and } 14 \text { of the Văt Luong } \\
\text { Kău inscription K. } 365\end{array}$ \\
\hline $\begin{array}{l}\text { Kutai (East Kalimantan or } \\
\text { Borneo, Indonesia), Mūla- } \\
\text { varman, the fifth century }\end{array}$ & 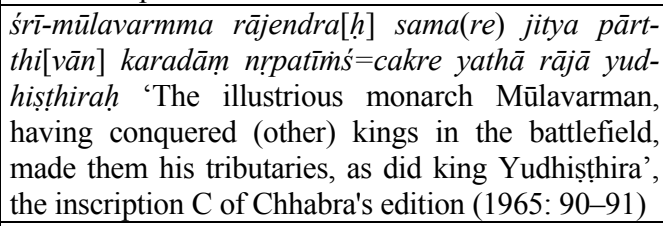 \\
\hline $\begin{array}{l}\text { Tarumanagara (West Java, } \\
\text { Indonesia), Pūrnavarman, } \\
\text { the fifth century }\end{array}$ & $\begin{array}{l}\text { Pracuraripuśarabhedyavikhyātavarmmo 'famous } \\
\text { armour impregnable by the arrows of the hosts of } \\
\text { foes'; arinagarotsādane 'destroying of the enemies' } \\
\text { cities'; śalyabhūtam ripūnām 'being the thorn to the } \\
\text { enemies', the Jambu Rock inscription; jayaviśälasya } \\
\text { 'great by victory', the Kebon-Kopi Rock inscription }\end{array}$ \\
\hline
\end{tabular}




\begin{tabular}{|c|c|}
\hline Kingdom/area/king/date & Inscriptional Evidence \\
\hline $\begin{array}{l}\text { Srivijaya (Southeast Suma- } \\
\text { tra, Indonesia), Śrī Jayanāśa } \\
\text { or Jayanāga, the seventh } \\
\text { century }\end{array}$ & 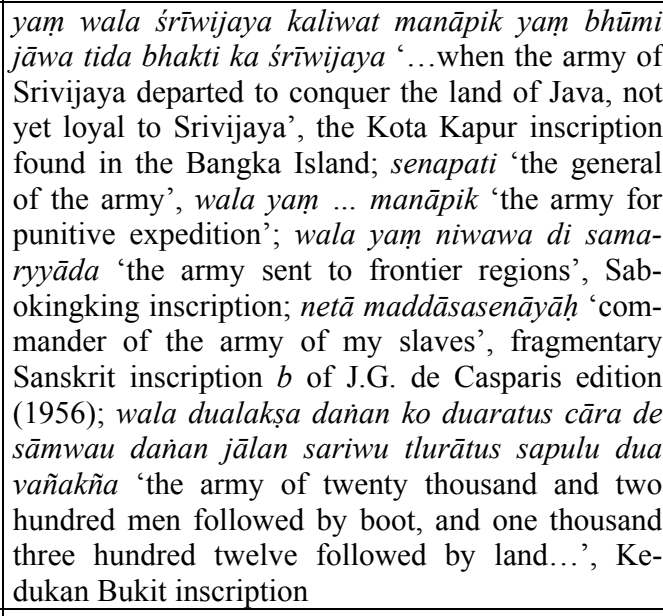 \\
\hline $\begin{array}{l}\text { Yava(dvīpa), (Central Ja- } \\
\text { va), Sañjaya, the eighth } \\
\text { century }\end{array}$ & $\begin{array}{l}\text { sannatārirmmanuriva 'having his enemies bent } \\
\text { down like Manu'; raghuriva vijjitānekasā (man- } \\
\text { taca)krah 'conqueror of many circles of vassal kings } \\
\text { (feudal lords)', the Canggal inscription of } 732 \mathrm{CE}\end{array}$ \\
\hline $\begin{array}{l}\text { Bhava, or Zhenla (Cambo- } \\
\text { dia), Bhavavarman, the } \\
\text { sixth - seventh centuries }\end{array}$ & $\begin{array}{l}\text { śărasanodyogajitārthadānai 'with gifts conquered } \\
\text { by the bow', the Battambang inscription K. } 213\end{array}$ \\
\hline $\begin{array}{l}\text { Bhava, or Zhenla (Cambo- } \\
\text { dia), Citrasena-Mahendra- } \\
\text { varman, the early seventh } \\
\text { century }\end{array}$ & $\begin{array}{l}\text { jitveman teśam akhilan 'having conquered the who- } \\
\text { le country', the inscriptions from Basak K. } 363 \text {, from } \\
\text { Ubon K. 496-497 and K. 508, from Khon Kaen } \\
\text { K. } 1102 \text {, from Phimai K. } 1106 \text {; vijitya nikhilān deśän } \\
\text { 'having conquered all the countries', the inscriptions } \\
\text { from Ubon K. } 509 \text { and from Surin K. } 377\end{array}$ \\
\hline $\begin{array}{l}\text { Bhava or Zhenla (Cambo- } \\
\text { dia), Íśānavarman I } \\
(\approx 616-637)\end{array}$ & $\begin{array}{l}\text { tena bhīmibhujā vyāptadiśa mandalakīttinā 'by } \\
\text { this king who conquered the country and who is } \\
\text { famous in all the circle of kings', inscription from } \\
\text { Sambor Prei Kuk K. } 604627 \mathrm{CE}\end{array}$ \\
\hline
\end{tabular}

Sources: Filliozat 1969; Coedès 1930, 1931, 1952, 1953, 1956; Chhabra 1965; Vogel 1918, 1925; De Casparis 1956; Kullanda 2001; Barth 1885, 1903; Finot 1928; Seidenfaden 1922.

Table 1 shows, at the first glance, the role of warfare as a factor of state formation and/or military function of royal power. It is a wellknown fact that kings were the military leaders in all later state formations. The Shang Dynasty in China, the Hittite Kingdom in Asia Minor, Assur and Mitanni, Vedic Aryans in the second millennium BCE share this feature. The military function of royal power is evident in Southeast Asian inscriptions independently of their languages, be it Sanskrit and Old Malay. 
But it is the question whether the mentioning of victories reflects the ideology of royal power only. One may hypothesize that at least Sanskrit inscriptions describe totally fictitious events, aiming to praise the kings who ordered these texts. But Old Malay inscriptions of Srivijaya show that the victories of the King of Srivijaya were real events because his navy visited and subdued such regions outside his capital at Palembang as the Island of Bangka, the Batang Hari River Basin, and the southern parts of Sumatra. There were areas where the inscriptions of Kota Kapur, Kerang Brahi, Bungkuk, and Palas Pasemah were found (see Fig. 2).

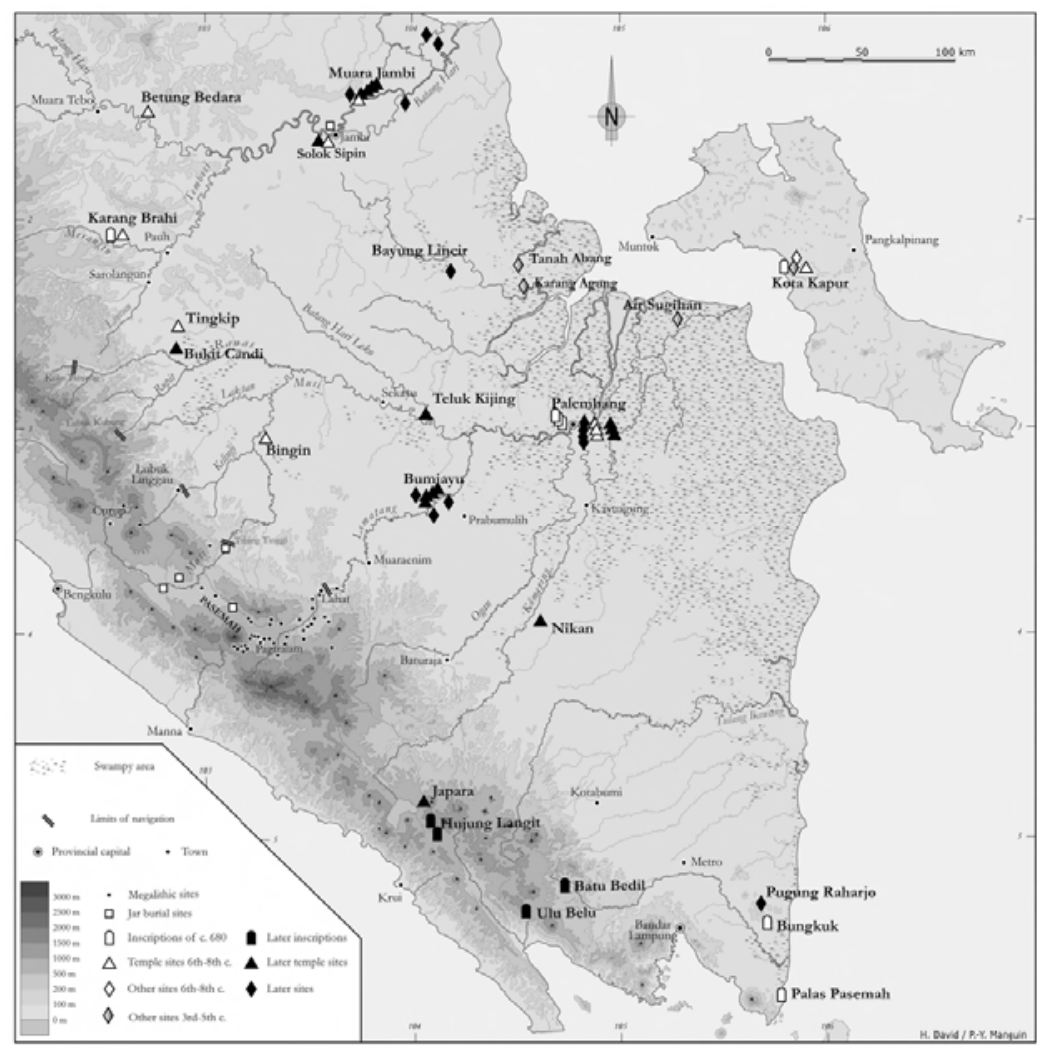

Fig. 2. Archaeological Sites of Southeast Sumatra in the seventh century Source: Manguin 2009, 437, Fig. 19-1

Three cases of Insular Southeast Asia are problematic due to the absence of relevant non-epigraphic data; these are the kingdoms of Tarumanagara in the West Java, of Kutai under Mūlavarman in Southeast Borneo or East Kalimantan, and of Sañjaya in Central Java. 
But the inscriptions of Gunavarman and the early kings of Bhava may be compared with the Chinese chronicles.

The Pràsàt Prằm Lovên inscription of Gunavarman K. 5 found on the hill Tháp-mười in the Plain of Reeds (Plaine des Joncs), mentions a certain King Jayavarman who probably was the father of Gunavarman (nrpatir jja[yavarman], line 3, strophe II; gunavarmmanāmā... yene ... janitā, lines 10-1, stanza VI, Cœdès 1931: 5-6). Jayavarman is mentioned in the inscription of another king - Rudravarman, from Ta Prohm K. 40 in the District of Bati, the Takéo Province of Cambodia.

The inscription K. 40 says Jayavarman was Rudravarman's father: tatpitrā jayavarmman̄a nrpatinādhyakșo dhanānām kṛtaś 'His father, king Jayavarman, ordered his son a superintendent over property...' (cf. Coedès' translation: 'Le père de ce (roi), le roi Jayavarman, nomma inspecteur des biens le fils d'un religieux chef des brahmanes...', line 9, strophe V; Cœdès 1931: 10-11). She-ye-ba-mo - Jayavarman 闍耶跋摩 (died 514) occurs in the Chinese standard history 'Nan Qi shu' 南齊書 (History of the Southern Qi) (Pelliot 1903: 257). He sent the mission to the Chinese court with the Buddhist monk Nàqiéxiān mentioned above, and asked the Chinese for the military help against the Kingdom of Linyi 林邑. 'Nan Qi shu' tells about the raids of the Funanese against Linyi and stresses that both Funan and Linyi liked to subdue their neighbours (Pelliot 1903: 262, 261, see above).

Jayavarman and his son Liu-to-ba-mo - Rudravarman - 留陁跋摩 are both mentioned in the 'Liang shu' 梁書 (The Book of Liang) (Pelliot 1903: 269-70). Despite the 'Liang shu' silence about wars of these kings, it may be accounted for by the bias of the text's authors. They emphasize the regular tributes from Funan and its loyalty to the Chinese emperor. The silence of the 'Liang shu' contradicts the statements by the 'Nan Qi shu'. But, comparing the inscriptional and Chinese evidence, one may take the military actions by Jayavarman and his sons for granted.

The Chinese texts inform that the decline of Funan was connected with the activities of two kings Citrasena and İsananavarman. The 'Sui shu' 隋書 (Book of Sui) by Wei Zheng (581-643), finished in $636 \mathrm{CE}$, tells,

The Kingdom of Zhenla is to the southwest of Linyi and was originally subject to Funan... The surname of its [former] king was that of the Cha-li clan; his given name was Zhiduo-si-na 質多斯那. His ancestors had gradually become more powerful and flourishing until the time of Zhi-duo-sina [himself], who annexed Funan and possessed it. When he 
died, his son Yi-she-na-xian 伊奢那先代 took his place. He lives in Yi-she-na City; there are over 20,000 thousand households below its walls... Altogether, there are 30 large cities. Cities have thousands of households; each has a Division Leader (bushuai). Official titles are the same as [those used in] Linyi (Aspell 2013: 17-18; cf. Pelliot 1903: 272; Cœdès 1943: 1).

According to the 'Xin Tang shu' 新唐書 (New Book of Tang) compiled in the eleventh century by Ouyang Xiu and Song Qi, 'the kingkșatriya Yi-sha-na subdued Funan and annexed its territory in the beginning of the era Zhenguan (627-649) [when Emperor Taizong of Tang ruled]' (Pelliot 1903: 275. Ma Duanlin 馬端臨 in his encyclopedia 'Wenxian Tongkao' 文獻通考 (General Study of the Literary Remains, $\approx 1254-1323$ ) follows the 'Sui shu' (Ma-Touan-Lin 1883: 476483; Cœdès 1968: 74-76).

These evidence shows that the aggressive, or military policy of Citrasena-Mahendravarman and Ísānavarman is not only propaganda of the authors of their inscriptions. If the information about two conquests of Funan is correct, one may suppose a cyclical nature of political development: a new ruler had to reconquer and/or re-subdue his neighbours. The history of the Funan Kingdom shows the same political model: there were three consecutive dynasties of Hun, Fan, and Varman (see Briggs 1951; Cœdès 1968).

The similarity between the official titles in Zhenla and Linyi mentioned by the 'Sui shu' and by 'Wenxian Tongkao,' needs to be clarified. Recently William Aspell translated Chapter 47 of the 'Sui Shui' as follows:

They have two honored officials. The first is called Xi-na-po$d i$; the second is called Sa-po-di-ge. They have three ranks of subordinate officers: the first is called Lun-duo-xing, followed by Ge-lun-zhi-di, followed in turn Yi-ta-qie-lan. Outer officials (waiguan, officials serving outside the capital) are separated into over 200 divisions. The senior officials [of this category] are called Fu-luo. Those next in rank are called $\mathrm{Ke}$ lun. They are like the clerks (chai) of regional governors and district magistrates (in China) (Aspell 2013: 9).

The term Xi-na-po-di is obviously Sanskrit senāpati 'the army commander.' Aspell treats the word Sa-po-di-ge as Sanskrit sarvādhikārin 'General Superintendent' (Aspell 2013: 9, n. 23). Fu-luo reflects Sanskrit putra 'a son', probably, it is a reflection of räjaputra 'royal son, prince' (op. cit., n. 26). Aspell believes the title Ku-lun 
reflects an Old Khmer title kloñ/khloñ which is well-known in epigraphic records ${ }^{5}$ (s.v. 'id.').

In any case, the sources show a developed political system but they may be less reliable when speaking about administrative hierarchy. The data of the 'Sui shu' may well be a super-imposition of the Chinese views on state structure over a totally different Old Khmer social system. So I decided to combine the inscriptional and eo ipso local data on the royal and official titles and on territorial divisions in a table, to juxtapose them with the Chinese descriptions of early Zhenla and, to some extent, of Southeast Asia (see Table 2).

Table 2

Political and Spatial Terminology in early royal inscriptions of Southeast Asia ${ }^{6}$

\begin{tabular}{|c|c|c|c|}
\hline King & $\begin{array}{l}\text { Country/ } \\
\text { region }\end{array}$ & Time & Terms \\
\hline śrīmāra & $\begin{array}{l}\text { Vo-canh, Nha } \\
\text { Trang, Cen- } \\
\text { tral Vietnam }\end{array}$ & $\begin{array}{l}\text { the fourth-fifth } \\
\text { centuries }\end{array}$ & $\begin{array}{l}\text { śrīmāra (< Tamil māRaN } \\
\text { 'gold'), sadas, bhṛtya }\end{array}$ \\
\hline $\begin{array}{l}\text { Gunavarman, son } \\
\text { of Jayavarman }\end{array}$ & Funan & $\begin{array}{l}\text { the fifth } \\
\text { century }\end{array}$ & $\begin{array}{l}\text { n̦rpati, narādhipati, avanīd- } \\
\text { harapati (conjectural), va- } \\
\text { sudhādhipa }\end{array}$ \\
\hline Rudravarman & Funan & $\begin{array}{l}\text { the fifth-sixth } \\
\text { centuries }\end{array}$ & narādhipa, nṛpati \\
\hline Kulaprabhāvati & Funan & $\begin{array}{c}\text { the fifth-sixth } \\
\text { centuries }\end{array}$ & $\begin{array}{l}\text { rājñ̄ī, nṭpati, rājan, bhoga, } \\
\text { vipra, pura, }{ }^{7} \text { bhū, nagara }\end{array}$ \\
\hline Devānīka & $\begin{array}{l}\text { Vat Phou, } \\
\text { Laos }\end{array}$ & $\begin{array}{l}\text { the fifth-sixth } \\
\text { centuries }\end{array}$ & $\begin{array}{l}\text { narendrah̆, mahārājādhi- } \\
\text { rāja, mahādhirājya, nṛpa, } \\
\text { sadasya, jāna, mahātīrt- } \\
\text { tha, pṛthivī, deśa }\end{array}$ \\
\hline Bhavavarman & $\begin{array}{l}\text { Si Thep, } \\
\text { Thailand }\end{array}$ & $\begin{array}{c}\text { the sixth- } \\
\text { seventh centuries }\end{array}$ & rājan, rājya \\
\hline Bhavavarman & Bhava/Zhenla & the sixth century & nrpa \\
\hline $\begin{array}{l}\text { Citrasena- } \\
\text { Mahendravarman }\end{array}$ & Bhava/Zhenla & $\begin{array}{c}\text { the sixth- } \\
\text { seventh centuries }\end{array}$ & $\begin{array}{l}\text { rājan, abhiṣeka, deśa, } \\
\text { rājya }\end{array}$ \\
\hline İsāanavarman & Bhava/Zhenla & $\begin{array}{c}\text { the seventh } \\
\text { century }\end{array}$ & $\begin{array}{l}\text { rājan, kșitipa, kșitīía, } \\
\text { kṣoṇīndra, nụpati, sāman- } \\
\text { tanṛpa, sāmantanareśvara, } \\
\text { pureśvara, bhūmibhuj, } \\
\text { avanibhuj, prrthivībhuj, na- } \\
\text { rādhipati, svāmin, bhṛtya, } \\
\text { adhikṛta, ācārya, vrah } \\
\text { kamratāñ añ, poñ, mratāñ } \\
\text { khloñ, maṇ̣ala, pura, na- } \\
\text { gara, grāma, vihāra, diś }\end{array}$ \\
\hline
\end{tabular}




\begin{tabular}{|c|c|c|c|}
\hline King & $\begin{array}{l}\text { Country/ } \\
\text { region }\end{array}$ & Time & Terms \\
\hline Bhadravarman & $\begin{array}{l}\text { Thu Bồn } \\
\text { River Valley, } \\
\text { Central } \\
\text { Vietnam }\end{array}$ & $\begin{array}{l}\text { the fifth-sixth } \\
\text { centuries }\end{array}$ & $\begin{array}{l}\text { mahārāja, rājan, raja- } \\
\text { mātra, dharmamahārāja, } \\
\text { janapada, anugraha (land } \\
\text { endowment) }\end{array}$ \\
\hline Kandarpadharman & Campā, Huế & the sixth century & campeśvara, pureśvara \\
\hline $\begin{array}{l}\text { Prakāśadharman- } \\
\text { Vikrāntavarman }\end{array}$ & Campā & $\begin{array}{c}\text { the seventh } \\
\text { century }\end{array}$ & 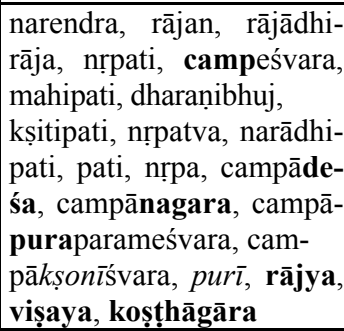 \\
\hline Mūlavarman & $\begin{array}{l}\text { East } \\
\text { Kalimantan, } \\
\text { or Borneo }\end{array}$ & the fifth century & $\begin{array}{l}\text { rājan, pārthiva, narendra, } \\
\text { bhūmidāna (gift of land), } \\
\text { pura }\end{array}$ \\
\hline Pūrṇavarman & Western Java & the fifth century & $\begin{array}{l}\text { avanipati, narapati, nrpa, } \\
\text { narendra, pura, nagara, } \\
\text { śibira }^{8}\end{array}$ \\
\hline Jayanāśa & $\begin{array}{l}\text { Srivijaya, } \\
\text { Sumatra }\end{array}$ & $\begin{array}{l}\text { the seventh } \\
\text { century }\end{array}$ & $\begin{array}{l}\text { kadātuan, wanua, bhūmi, } \\
\text { dātu, dapunta hiyang, hu- } \\
\text { luntuhān 'slaves and lords, } \\
\text { subjects, empire' }\end{array}$ \\
\hline Sañjaya & Central Java & $\begin{array}{l}\text { the eighth } \\
\text { century }\end{array}$ & $\begin{array}{l}\text { narapati, prabhu, rājan, sā- } \\
\text { manta, dvīpa, deśa, rājya }\end{array}$ \\
\hline
\end{tabular}

Sources: Cœdès, 1930, 1931, 1937, 1942, 1951, 1952, 1953, 1954, 1956, 1964, 1966; De Casparis 1956; Sarkar 1971; Vogel 1918, 1925; Finot 1902, 1928; Barth 1885, 1903; Filliozat 1969; Jacques 1986; Zakharov 2015.

\section{ROYAL EPIGRAPHY AND TERRITORIAL DIVISION}

The dominance of royal titles over official titles in Sanskrit inscriptions reflects the focusing on the figure of the king. In vernacular languages inscriptions, one can find more profound lists of officials and other subjects. The Old Malay Sabokingking inscription of Srivijaya claims:

Kāmu vañak=māmu rājaputra proștāra bhūpati senapati nāyaka pratyaya hājipratyaya daṇd̦anāyaka ... mūrddhaka tuhā an vatak=vuruh addhyākșī nījavarṇa vāṣīkaraṇa kumārāmātya cātabhața adhikaraṇa karmma ... kāyastha sthāpaka puhāvam vaṇiyāga pratisāra dā ... kāmu marsī hāji hulun=hāji vañak=māmu urạn nivunuḥ sumpaḥ' [3] All of you, as many as you are, - sons of kings, ... chiefs, army commanders, nayyaka, pratyaya, confidants (?) of the 
king, judges, [4] chiefs of ...(?), surveyors of groups of workmen, surveyors of low-castes, cutlers, kumārāmātya, cātabhața, adhikaraṇa, ... clerks, sculptors, naval captains, merchants, commanders, ... and you - [5] countrymen of king and slaves of the king, - all of you will be killed by the curse of (this) imprecation (De Casparis 1956: 32-33, 3638 with corrections). ${ }^{9}$

The seventh century seemingly was an age of transition in the political development of early Southeast Asia. Three kingdoms left inscriptions which contain the data on the idea of territorial or administrative division, at least of spatial hierarchy. The term mandala in the statement sakalamaṇdalāña kadātuanku 'you, who protect all the provinces of my kingdom-kadätuan' refers to the territories small in size (cf. Casparis 1956: 35). But this term was not found in the other inscriptions of Srivijaya found outside of its centre near Palembang - in the Batang Hari River Valley, in the Bangka Island, in Lampung in South Sumatra. The ruler of Srivijaya, the King Śrī Jayanāśa had the title of dātu as well as his subjects or vassal rulers. He claimed that he ordered other dātu but we cannot substantiate this statement of the twentieth line of the Sabokingking inscription.

The only case in early royal Southeast Asian epigraphy when mandala denoted a circle of kings is the Sambor Prei Kuk inscription K. 604 of 627 CE found in the edifice $F_{3}$ of the temple S; the Kampong Thom Province of Cambodia. It mentions the King Ísānavarman and his servant (bhṛtya) Vidyāviśeșa who erected the lingam of Shiva. The strophe VII says that 'The king, who conquered the country and who is famous in all the circle of kings, appointed his servant superintendent of all lands and duties' (tena bhümibhujā vyāptadiśa mandalakīrttinā bhrtyo yo 'dhikrtas sarvveșv itikarttavyavastuṣu; Finot 1928: 44-45; Cœdès 1952: 17-19). ${ }^{10}$ Here we also find the term diś 'country'.

Another servant - bhrtya of İ́ānavarman I named Iśvarakumāra was appointed protector of the city Jyeșthapura, according to the Khau Noy inscription K. 506 dated from $637 \mathrm{CE}$ and found in the Province Prachinburi of Thailand. Ísvarakumāra is also called the lord of Jyeșthapura - svāmin, mratañ khlon (Jacques 1986: 81; Cœdès 1953: 23). An undated inscription from Vat Prei Veng K. 80 found in the Kandal Province of Cambodia calls İsānavarman I 'illustrious lord of three kings, grantor and powerful lord of three invincible cities-nagara, victorious lord of the Earth, whose power is that of Hara' (bhüpatrayasyoruyaśo vidhātā bhoktā valīyān nagaratrayasya śaktitrayasyeva hara sthirasya śrīsānavarmmā jayati kșitīśạ; Cœdès 1954: 4).

These data show that under Ísānavarman I's reign there was administrative personnel which included royal servants - bhrtya who were 
appointed to various posts. The data also reveal that the country - diś and the 'circle of kings' - mandala included land plots and cities (vastu. pura and nagara). The country - diś seemingly meant the kingdom - räjya. The difference between the meanings of the term mandala in Srivijaya and in Bhava-Zhenla reflects the differences in localized forms of Sanskrit.

The term deśa 'country' occurs in the inscriptions of CitrasenaMahendravarman from Phu Lokhon, Basak, Laos, K. 363, from Pak Mun or Khan Thevada K. 496-497, Ubon, Thailand, say that this king 'conquered all the country': jitveman teśam ${ }^{11}$ akhilan (Barth 1903: 442-446; Cœè̀s apud Seidenfaden 1922: 57-60; Jacques 1986: 66). His other records from Tham Prasat, Ubon, K. 509, and from Vat Sumphon, Surin, Thailand, K. 377 give another rendering of the same sentence vijitya nikhilān deśän 'having conquered all the countries' (Cœdès apud Seidenfaden 1922: 58-59; Vickery 1998: 74-75; Cœdès 1953: 3-4; Cœdès 1935: 380-384). Hence, the term deśa could refer to various countries as well as the territory subject to Citrasena.

That maṇdala replaced deśa in the age of İsānavarman I may reflect his growing claims to the control over the conquered lands of Funan and/or to more sophisticated political vocabulary.

The kings Bhadravarman and Prakāśadharman-Vikrāntavarman who ruled over the Thu Bồn River Valley and over some other territories in present Central Vietnam left inscriptions containing some spatial terms. These kings are usually believed to be the rulers of the ancient kingdom of Campā (Majumdar 1927; Coedès 1968). Their kindred are still problematic but they both patronized the temple complex of Mỹ Sơn where the majority of their inscriptions have been found.

The Mỹ Sơn inscription C. 72 says that Bhadravarman bestowed a plot of land with householders as immunity, to the god Bhadreśvara (lines A.5 and 7): bhadreśvarāya aksaȳ n̄ivì dattā; sakuțumbijanā bhümi dattā (Finot 1902: 188-189; Majumdar 1927: 5-6). After the first sentence one finds the term janapadamaryyād $\bar{a}(h)$ - 'boundaries of the country.' It is the only occurrence of the word janapada in early Campā inscriptions. This word has a peculiar place in the ancient Indian theory of statehood: as an 'inhabited country', janapada was among the seven jewels of kingdom, along with the king, the minister, the capital city, the treasure, the army, and the allies.

Certainly, the land given to Bhadreśvara did not cover all the lands of Bhadravarman's kingdom. The boundaries of the immunity were confirmed by another inscription of Bhadravarman from Chièm Son C. 147 (Finot 1918: 13). Therefore, I would suggest the land surveying in his realm. The term janapada, perhaps, denoted the kingdom but it is not certain. 
The facts quoted above show that the word bhümi, like mandala, had different meanings in Campā and Srivjiaya. In the former it meant a plot of land or a land bestowal while in the latter it covers the whole country. Interestingly enough, the yüpa inscriptions of King Mūlavarman from Borneo contain the compound bhümidāna 'the gift of land', or bestowal. This gift was received by the priests - viprāh, or Brahmins. It means that in this case the word bhumi referred to a part of the kingdom.

The Mỹ Sơn inscription of Prakāśadharman-Vikrāntavarman C. 96 dated from $658 \mathrm{CE}$ contains an informative passage on its face $\mathrm{B}$ (lines 23-25):

...loṅ-koșthāgāram sa-caum-vișayam havauñ-karnnauy-caupitau-krauñ-najoc-vasauy-koșthāgāra di midit tatrasahitam sarvvam idam śrīmāñ chrī campeśvara śrī prakāśadharmmā bhagavatām īśāneśvara-śríśambhubhadreśvara-śrīprabhāseśvarāṇām satatapūjāvidhaye prādāt \|| 'Koșthāgāra ${ }^{12}$ of Lon, with the district (visaya) ${ }^{13}$ of Caum and the kosthhāgarras of Havaun, Karnauy, Cau, Pitau, Kraun, Najoc, and Vasauy in [the district of] Midit, ${ }^{14}$ - all these have been given by the illustrious ${ }^{15}$ Śrī Prakāśadharman, lord of Śri Campa $\bar{a}^{16}$ for the eternal ${ }^{17}$ worship of the gods İśāneśvara, Śrī Sambhubhadreśvara and Śrī Prabhāseśvara' (Majumdar 1927: 26, with corrections in italics).

The passage shows that there were at least two visaya (Caum and Midit) and they included many kostthāgāra. It is hardly likely that Prakāśadharman-Vikrāntavarman left nothing for himself. One should suppose that he had other koșthāgāra and, possibly, taking into account the geographical space of his power and his conquest(s), other vișaya in different parts of his kingdom. I think we see here evidence of some degree of territorial division. I would also add here that Prakāśadharman-Vikrāntavarman was a grandson of İsāanavarman I of Bhava, according to the same Mỹ Son inscription C. 96 (Finot 1904: 918-925).

\section{CONCLUSIONS}

Kingdoms of Bhava and Campā led active foreign policies and possessed administrative personnel and territorial division. Their kings granted land to their servants and priests. These kingdoms had a developed political system and may be called early states.

Warfare was a factor in Southeast Asian state formation but this process was also influenced by the developments of world trade (Hall 1985; Wang Gungwu 1958). The struggle for the control over trade roots and sources of income as well as adoption of Indic writing and 
religious systems helped to form relatively large-scale kingdoms that, in turn, were able to send missions to China.

Current historiographic trends to connect the formation of the territorial states with the Angkor Empire dated from the ninth to thirteenth century were explicitly formulated by Vickery (1998) and O'Reilly (2007). Early scholars Cœdès (1944, 1948, and 1968) and Majumdar (1937) also viewed the Angkor Empire as a new epoch in the history of Southeast Asia. Cœdès, Majumdar, Chhabra (1965) and other historians took the pre-Angkorean times from the fifth to eighth centuries as a single epoch that had no considerable inner transformation. Oliver Wolters (1982) emphasizes the peculiarity and exclusively local nature of Southeast Asian polities that, in his views, have nothing in common with the state; Wolters makes use of the Sanskrit term mandala to describe the specific Southeast Asian political organization.

Contrary to the emphasis on the Angkor Empire as a turning point of Southeast Asian state formation, I suppose that the territorial states emerged in the region no later than the seventh century. I also think that many local polities since the seventh century were the states, and their nature is better understood in common terms instead of local coined words, such as Wolters' mandala. I also state that the seventh century was the turning point in the history of Southeast Asian state formation, pace Cœdès and Vickery. Therefore, conventional history of the region expressed by Cœdès in his famous and long-living textbook (1968) should be reappraised.

\section{NOTES}

${ }^{1}$ The undated Old Cam inscription of Đông Yên Châu C. 174 may be dated from the fifth as well as sixth century, but shows no sign of royal name; it also seems to have a pure religious content (Cœdès 1939).

${ }^{2}$ Claude Jacques believed that it reflects swidden or shifting agriculture (Jacques and Lafond 2007: 51). Paul Wheatley (1983: 79) supposed that the people of Funan used ratooning for irrigated rice cultivation. Kenneth Hall recently interpreted this sentence literally, 'in one year they sow and harvest for three (i.e., they leave it in and it will grow back three years before they have to replant)' (Hall 2011: 48). Michael Coe rightly noticed that 'one can only speculate about the way rice was grown' (Coe 2003: 55; cf. Higham 2001: 33).

${ }^{3}$ Translation is a bit incorrect in Cœdès' monograph: the French term 'villes' turns to 'villages' instead of 'cities.' I decided to restore Pelliot's original translation.

${ }^{4}$ The catalogue numbers of the inscriptions of Cambodia are denoted by the letter K (Sanskrit Kamboja); that of Campā/Champa by the letter C (Cœdès 1908; 1937; 1942; 1966; Cœdès and Parmentier 1923; Griffiths et al. 2012).

${ }^{5}$ URL: http://sealang.net/ok/. 
${ }^{6}$ The Table is not exhaustive. Many inscriptions are still unpublished and, therefore, inaccessible to me. Other inscriptions are published in parts. So I highly appreciate the additions to the Table.

${ }^{7}$ All spatial terms are given in bold for the sake of convenience.

${ }^{8}$ Śibira may mean a camp or tent.

${ }^{9}$ The word proștâra is not clear. The ambivalence of the term bhüpati in Sanskrit does not allow defining its exact meaning in this context. It could mean 'vassal', although the term 'chief' was used in translation by De Casparis (1956: 19, 37, n. 4). De Casparis believes the term mürddhaka denotes a leader of a certain group of people, and translates this word as 'chief of' (1956: 19-20, 37). But this interpretation is doubtful. First, there is a lacuna in the inscription before this word. Second, it means kșatriya in Sanskrit (Böhtlingk 1884: 95). The translation of amätya 'minister' seems to be unconvincing. It is more likely 'an associate, a companion' (Leliukhin 2001: 23-24). The expression marsī hāji was translated as 'washermen of king' by De Casparis but Alexander Adelaar (1992: 393-396) offered another interpretation 'intimates' basing on Salako analogues with Old Malay and Malay vocabulary and implying the meanings of 'the inner circle of the king', 'members of the court', or even 'relatives'. Following Adelaar, Waruno Mahdi (2005: 197) writes 'countrymen of the ruler'. It is worth noting that the Old Malay text contains the term senapati which was used in Linyi, according to the Chinese chronicles.

${ }^{10}$ Vastu means a plot of land in epigraphy and in 'Arthaśāstra' (Vigasin and Samozvantsev 1984: 155-160; Sircar 1966: 367). Itikartavya is a 'duty, obligation' (Monier-Williams 1899: 165).

${ }^{11}$ Read deśam.

${ }^{12}$ Majumdar translates the term as 'store-house'; Southworth writes about 'store-house, granary' (2001: 232). Finot offers 'domaine' (1904: 925). Griffiths and Southworth translate 'silo' in their editions of the steles from Phườc Thiện C. 217 and from Hoà Lai C. 216 (2007: 360, 363-364; 2011: 280, 283). While 'silo' may mean 'a tall tower or pit on a farm used to store grain', it also denotes 'a pit or other airtight structure in which green crops is compressed and stored as silage' (URL: http://www.oxforddictionaries.com/definition/english/silo accessed on 19 April 2014). It seems better to avoid connotations with silage, taking into consideration that one of the kosthāagara mentioned by C. 217 bears the name Devapura. Otto Böhtlingk (1881: 105) gives the meaning 'Kornkammer; eine umschlossene Fläche, Feld'. Monier-Williams adds 'store-room, a store; treasury' (1899: 314). Sircar proposes 'the royal granary' (1966: 160). In any case, these kosthāgāras were viewed as a source of stable income to upkeep the worship of three gods. They could be fields, storehouses that kept cereals from certain fields, and, less likely, treasuries: there are too many treasuries to be cessions of royal income. Finot's variant 'domain' or 'estate' seems good but we do not know how these kosththāāras were organized and what rights were transferred to the gods. If I may allow myself to speak of such facets - I feel inclined to speak in terms of a temple complex, as this would be more convenient and in accordance with usual practice in India and Southeast Asia, but for the sake of accuracy I try to avoid interpretation where one needs a strict translation.

It is in any case noteworthy that the term kosthāgāra occurs in the Vỏ-Canh inscription (C. 40) mentioned above (line 13; Filliozat 1969: 113). Jean Filliozat 
translates it as 'le trésor' (Ibid.: 114), that is 'hoard' or 'treasury'. I may recall here that there is no scholarly consensus on whether the Vỏ-Cạnh inscription belongs to 'Campā culture' or not.

${ }^{13}$ The term vișaya has various meanings: 'sphere (of influence or activity), dominion, kingdom, territory, region, district, country, abode' (Monier-Williams 1899: 997). Sircar (1966: 377) states: 'a district; often a kingdom or territory; sometimes a visaya was included in a mandala; but, in some cases, a mandala was included in a vișaya; at times mandala and vișaya were synonymous'. Perhaps, other variants include 'area' and 'locality'. Griffiths and Southworth hold that vișaya could mean 'territory' or 'province' analyzing the term pāndarañgavisaya in the inscription of Hoà Lai C. 216 whose principal part dates from $778 \mathrm{CE}$ (2011: 279, 282, 285-291). The inscription belongs to another group of Campā texts than the Mỹ Sơn inscription C. 96: it concerns the southern polity of Pāṇụranga and dates from a hundred years later. Hence, the term vișaya could have slightly or even markedly different meanings in these inscriptions.

${ }^{14}$ It is curious that the Sanskrit text contains the Old Cam preposition $d i$ : koșthāgāra di midit (cf. earlier lon-koșthāgāram sa-caum-vișayam that presents two Sanskrit compounds of the tatpuruṣa type, like kandarpapura).

${ }^{15}$ Majumdar omits śrimāã in his translation.

${ }^{16}$ Majumdar writes 'king of Champā'.

${ }^{17}$ Majumdar omits satata in his translation.

\section{REFERENCES}

Acri, A., Blench, R., and Landmann, A. (eds.) 2017. Spirits and Ships: Cultural Transfers in Early Monsoon Asia. Singapore: ISEAS; Yusof Ishak Institute (Nalanda-Sriwijaya Series).

Adelaar, A. 1992. The Relevance of Salako for Proto-Malayic and for Old Malay Epigraphy. Bijdragen tot de Taal-, Land-en Volkenkunde (further - BTLV) $148(3-4): 381-408$.

Aspell, W. 2013. Southeast Asia in the Suishu: A Translation of Memoir 47 with Notes and Commentary. Asia Research Institute Working Paper No. 208, September. URL: www.ari.nus.edu.sg/pub/wps.htm.

Barth, A. 1885. Inscriptions sanscrites du Cambodge. Paris: Imprimérie Nationale.

Barth, A. 1903. Inscription sanskrite de Phou Lokhon (Laos). Bulletin de l'École Française d'Extreme Orient (further - BEFEO) 3 (3): 442-446.

Bergaigne, A. 1893. Inscriptions sanskrites de Campā et du Cambodge. Paris (Notices et extraits des manuscrits de la Bibliothèque nationale 37 (1)).

Boechari. 1979. An Old Malay Inscription at Palas Pasemah (South Lampong). Pra Seminar Penelitian Sriwijaya, Jakarta 1978 (pp. 19-42). Jakarta: Puslit Arkenas.

Boechari. 1986. New Investigations on the Kedukan Bukit Inscription. Pusat Penelitian Arkeologi Nasional, Untuk Bapak Guru. Persembahan para murid untuk memperingati Usia Genap 80 Tahun Prof. Dr. A. J. Bernet Kempers (pp. 33-56). Jakarta: Puslit Arkenas.

Böhtlingk, O. 1881. Sanskrit-Wörterbuch in kürzerer Fassung. T. 2. St. Petersburg: Buchdruckerei der kaiserlichen Akademie der Wissenschaften. 
Böhtlingk, O. 1884. Sanskrit-Wörterbuch in kürzerer Fassung. T. 5. St. Petersburg: Buchdruckerei der kaiserlichen Akademie der Wissenschaften.

Brandes, J. L. A. 1913. Oud-Javaansche Oorkonden. Nagelaten Transcripties. Uitgegeven door Dr. N. J. Krom. The Hague: Bataviaasch Genootschap (Verhandelingen van het Bataviaasch Genootschap van Kunsten en Wetenschappen 61).

Briggs, L. P. 1951. The Ancient Khmer Empire. Philadelphia: American Philosophical Society. (Transactions of the American Philosophical Society, Held in Philadelphia for promoting useful knowledge, New Series 41 (1)).

Chhabra, B. Ch. 1935. Expansion of Indo-Aryan Culture during the Pāllava Rule, as evidenced by inscriptions. Journal and Proceedings of the Asiatic Society of Bengal (Letters) 1 (1): 1-64, 7 pl.

Chhabra, B. Ch. 1961. Bangkok Museum Stone Inscription of Mahendravarman. Journal of the Siam Society 49 (2): 109-111.

Chhabra, B. Ch. 1965. Expansion of Indo-Aryan Culture during the Pāllava Rule (as evidenced by inscriptions). Delhi: Munshi Ram Manohar Lal.

Claessen, H. J. M., and Skalník, P. (eds.). 1978. The Early State. The Hague: Mouton.

Claessen, H. J. M., and Skalník, P. (eds.). 1981. The Study of the State. The Hague: Mouton.

Claessen, H. J. M., and Oosten, J. G. (eds.). 1996. Ideology and the Formation of Early States. Leiden: E. J. Brill.

Coe, M. D. 2003. Angkor and the Khmer Civilization. New York: Thames \& Hudson.

Cœdès, G. 1908. Inventaire des inscriptions du Champa et du Cambodge. BEFEO 8 (1): 37-92.

Cœdès, G. 1912. Note sur deux inscriptions du Champa. BEFEO 12 (8): 15-17.

Cœdès, G. 1930. Les inscriptions malaises de Çrīvijaya. BEFEO 30: 29-80.

Cœdès, G. 1931. Etudes cambodgiennes. XXV. Deux inscriptions sanskrites du Fou-nan. XXVI. La date de Kôh Ker. XXVII. La date du Bàphûon. BEFEO 31 (1): 1-23.

Cœdès, G. 1935. Review of: Chhabra B. Ch. Expansion of Indo-Aryan Culture during the Pâllava Rule, as evidenced by inscriptions. Journal and Proceedings of the Asiatic Society of Bengal (Letters) 1 (1): 1-64, 7 pl. BEFEO 35 (2): $380-384$.

Cœdès, G. 1937a. Inscriptions du Cambodge. T. 1. Hanoi: Imprimérie d'ExtrêmeOrient.

Cœdès, G. 1937b. A New Inscription from Fu-nan. The Journal of the Greater India Society 4 (2): 117-121.

Cœdès, G. 1939. La plus ancienne inscription en langue chame. Eastern and Indian Studies in Honour of F. W. Thomas, C. I. E. Bombay: New Indian Antiquary Extra Series 1, No. 48: 39-52.

Cœdès, G. 1942. Inscriptions du Cambodge. T. 2. Hanoi: Imprimérie d'ExtrêmeOrient.

Cœdès, G. 1944. Histoire ancienne des états hindouisés d'Extrême-Orient. Hanoi: Imprimérie d'Extrême-Orient. 
Cœdès, G. 1948. Les états hindouisés d'Indochine et d'Indonésie. P.: Editions de Boccard.

Cœdès, G. 1951. Inscriptions du Cambodge. T. 3. P.: École française d'ExtrêmeOrient.

Codès, G. 1952. Inscriptions du Cambodge. T. 4. P.: École française d'ExtrêmeOrient.

Cœdès, G. 1953. Inscriptions du Cambodge. T. 5. P.: École française d'ExtrêmeOrient.

Cœdès, G. 1954. Inscriptions du Cambodge. T. 6. P.: École française d'ExtrêmeOrient.

Codès, G. 1956. Nouvelles données sur les origines du royaume khmèr: la stèle de Văt Luong Kău près de Văt P'hu. BEFEO 48 (1): 209-220.

Cœdès, G. 1964. Inscriptions du Cambodge. T. 7. P.: École française d'ExtrêmeOrient.

Cœdès, G. 1966. Inscriptions du Cambodge. T. 8. P.: École française d'ExtrêmeOrient.

Coedès, G. 1968. The Indianized States of Southeast Asia / Ed. W. F. Vella, translated by S. Brown Cowing. Honolulu, Hawaii: East-West Center Press.

Coedès, G., and Parmentier, H. 1923. Listes générales des inscriptions et des monuments du Champa et du Cambodge. Hanoi: Imprimérie d'Éxtrême-Orient.

De Casparis, J. G. 1956. Selected Inscriptions from the 7th to the 9th Century A.D. [Prasasti Indonesia 2]. Bandung: Masa Baru.

Finot, L. 1902. Notes d'épigraphie: Deux nouvelles inscriptions de Bhadravarman Ier, roi de Champa. BEFEO 2: 185-191.

Finot, L. 1903. Notes d'épigraphie: Stèle de Çaṃbhuvarman à Mì-sơn. BEFEO 3: 206-13.

Finot, L. 1904a. Notes d' épigraphie: Inscriptions du Quang Nam. BEFEO 4 (12): 83-115.

Finot, L. 1904b. Notes d'épigraphie. BEFEO 4 (3): 672-679.

Finot, L. 1904c. Notes d'épigraphie: Les inscriptions de Mì-sơn. BEFEO 4 (3): 897-977.

Finot, L. 1915. Errata et addenda. BEFEO 15 (2): 185-190.

Finot, L. 1928. Nouvelles inscriptions du Cambodge. BEFEO 28: 43-80.

Glover, I. C., and Bellwood, P. (eds.). 2004. Southeast Asia: From Prehistory to History. London: Routledge Curzon.

Golzio, K.-H. 2004. Inscriptions of Campā based on the Editions and Translations of Abel Bergaigne, Étienne Aymonier, Louis Finot, Édouard Huber and other French Scholars and of the work of R. C. Majumdar: Newly presented, with minor corrections of texts and translations, together with calculations of given dates. Aachen: Shaker Verlag.

Griffiths, A., Lepoutre, A., Southworth, W. A. et al. 2012. Études du Corpus des inscriptions du Campā III. Épigraphie du Campā 2009-2010: Prospection sur la terraine, protection d'estampages, supplément à l'inventaire. BEFEO 95-96 pour 2008-2009: 437-97. 
Griffiths, A., Lepoutre, A., Southworth, W. A. et al. 2012. Văn Khắc Chămpa Tại Bảo Tàng Điêu Khắc Chăm - Đà Nẵng / The Inscriptions of Campā at the Museum of Cham Sculpture in Đà Nẵng. Hồ Chí Minh: VNUHCM Publishing House.

Griffiths, A., and Southworth, W. 2007. La stele d'installation de Śrī Satyadeveśvara: une nouvelle inscription sanskrite du Campā trouvée à Phướk Thiện. Journal Asiatique 295 (2): 349-381.

Griffiths, A., and Southworth, W. 2011. Études du Corpus des inscriptions du Campā II. La stèle d'installation de Śrī Ādidiveśvara: une nouvelle inscription de Satyavarman trouvée dans le temple de Hoà Lai et son importance pour l'histoire du Pāṇduranga. Journal Asiatique 299 (1): 271-317.

Grinin, L. E. 2008. Early State, Developed State, Mature State: The Statehood Evolutionary Sequence. Social Evolution \& History 7 (1): 67-82.

Hall, K. R. 1985. Maritime Trade and State Development in Early Southeast Asia. Honolulu: Hawaii University Press.

Hall, K. R. 2011. A History of Early Southeast Asia: Maritime Trade and Societal Development, 100-1500. Lanham - Boulder - New York - Toronto - Plymouth, UK: Rowman \& Littlefield Publishers, Inc.

Higham, Ch. 1996. The Bronze Age of Southeast Asia. Cambridge - New York: Cambridge University Press.

Huber, E. 1911. Etudes indochinoises. BEFEO 11: 259-311.

Jacques, Cl. 1986. Le pays Khmer avant Angkor. Journal des savants 1-3: 59-95.

Jacques, Cl., and Lafond, Ph. 2007. The Khmer Empire: Cities and Sanctuaries, Fifth to the Thirteenth Centuries. Bangkok: River Books.

Kathirithamby-Wells, J. and Villiers, J. (eds.) 1990. The Southeast Asian Port and Polity: Rise and Demise. Singapore: Singapore University Press, National University of Singapore.

Le Thi Lien. 2005. Gold Plaques and Their Cultural Contexts in the Ok Eo Culture. Bulletin of the Indo-Pacific Prehistory Association 25: 145-154 (Taipei Papers 3).

Leliukhin, D. N. 2001. The Conception of Ideal Kingdom in 'Arthaśāstra' of Kautilina and the Problem of Structure of the Ancient Indian State). In Leliukhin, D. N., and Liubimov, Yu. V. (eds.), The State in History of Society: To the Problem of the Criteria of the Statehood (pp. 9-148). 2nd ed., revised and enlarged. Moscow: Institute for Oriental Studies. Original in Russian (Лелюхин Д. Н. Концепция идеального царства в “Артхашастре” Каутильи и проблема структуры древнеиндийского государства. Государство в истории общества (к проблеме критериев государственности). 2-е изд. испр. и доп. М.: Институт востоковедения РАН).

Ma-Touan-Lin. 1883. Ethnographie des peuples étrangers à la Chine. T. 2. Méridionaux / traduit pour la première fois du Chinois avec un commentaire perpétuel par le marquis d'Hervey de Saint-Denys. Genève: H. Georg; Paris: E. Leroux; London: Trübner.

Mahdi, W. 2005. Old Malay. In Adelaar, A., and Himmelmann, N. P. (eds.), The Austronesian Languages of Asia and Madagascar (pp. 182-201). L. - N. Y.: Routledge. 
Majumdar, R. C. 1927. Ancient Indian Colonies in the Far East: Vol. 1. Champa. Book 3: The Inscriptions of Champa. Lahore: Punjab Sanskrit Books Depot.

Majumdar, R. C. 1937. Ancient Indian Colonies in the Far East: Vol. 2: Suvarnadvipa. Part 1: Political History. Dacca: Trailokya Chandra Sur Asutosh Press.

Malleret, L. 1959-1963. L'Archéologie du delta du Mékong. T. 1-4. Paris: Ecole Française d'Extrême-Orient, T. 1. L'exploration archéologique et les fouilles d'Oc-Ėo. 1959. T. 2. La civilisation matérielle d'Oc-Èo. 1960. T. 3. La culture du Fou-nan. 1962. T. 4. Le Cisbassac: Texte avec Index et Planches. 1963.

Manguin, P.-Y. 2000. City-States and City-State Cultures in pre-15th-Century Southeast Asia. In Hansen, M. H. (ed.), A Comparative Study of Thirty CityState Cultures: An Investigation Conducted by the Copenhagen Polis Centre (pp. 409-416). Copenhagen: C. A. Reitzels Forlag.

Manguin, P.-Y. 2002. The Amorphous Nature of Coastal Polities in Insular Southeast Asia: Restricted Centres, Extended Peripheries. Moussons 5: 73-99.

Manguin, P.-Y. 2004. The Archaeology of the Early Maritime Polities of Southeast Asia. In Glover, I. C., and Bellwood, P. (eds.), Southeast Asia: From Prehistory to History (pp. 282-313). London: Routledge Curzon.

Manguin, P.-Y. 2009. Southeast Sumatra in Protohistoric and Srivijaya Times: Upstream-Downstream Relations and the Settlement of the Peneplain. In Bonatz, D., Miksic, J., Neidel, J. D., and Tjoa-Bonatz, M. L. (eds.), From Distant Tales: Archaeology and Ethnohistory in the Highlands of Sumatra (pp. 434-484). Newcastle upon Tune: Cambridge Scholars Publishing.

Murphy, S. 2010. The Buddhist Boundary Markers of Northeast Thailand and Central Laos, 7th-12th Centuries CE: Towards an Understanding of the Archaeological, Religious and Artistic Landscapes of the Khorat Plateau. Thesis Submitted to the School of Oriental and African Studies, for the Degree of Doctor of Philosophy University of London.

Murphy, S. 2012. Measuring Mandalas in Early Southeast Asian Statecraft: A Case Study from the Chi River System of Northeast Thailand, c. 7th-11th Centuries CE. Paper presented to the 14th International Conference of the European Association of Southeast Asian Archaeologists, Dublin, Ireland, 18th 21st September.

O'Reilly, D. J. W. 2007. Early Civilizations of Southeast Asia. Lanham - New York - Toronto - Plymouth, UK: Altamira Press.

Pelliot, P. 1903. Le Fou-nan. BEFEO 3 (1): 248-303.

Pollok, Sh. 2006. The Language of the Gods in the World of Men: Sanskrit, Culture and Power in Premodern India. Berkeley, Los Angeles - London: University of California Press.

Sarkar, H. B. 1971. Corpus of the Inscriptions of Java (Corpus Inscriptionum Javanicarum) (up to 928 A.D.). Calcutta: Firma K. L. Mukhopadhyay. Vol. 2.

Seidenfaden, E. 1922. Complément à l'Inventaire descriptif des monuments du Cambodge pour les quatre provinces du Siam Oriental. BEFEO 22: 55-99.

Sircar, D. C. 1966. Indian Epigraphic Glossary. Delhi - Varanasi - Patna: Motilal Banarsidass. 
Southworth, W. A. 2004. The Coastal States of Champa. Glover, I. C., and Bellwood, P. (eds.) Southeast Asia: From Prehistory to History (pp. 209-233). L. - N. Y.: Routledge Curzon, Taylor and Francis Group.

Stark, M. 2004. Pre-Angkorian and Angkorian Cambodia. In Glover, I. C., and Bellwood, P. (eds.), Southeast Asia: From Prehistory to History (pp. 89-119). L. - N. Y.: Routledge Curzon, Taylor \& Francis Group.

Stein, R. 1947. Le Lin-yi, sa localisation, sa contribution à la formation du Champa et ses liens avec la Chine. Han-Hiue Bulletin du Centre d'Études Sinologiques de Pékin 2: 1-335.

Tingley, N. 2009. Arts of Ancient Viet Nam: From River Plain to Open Sea: With Essays by A. Reinecke, P.-Y. Manguin, K. Nguyen-Long, and Nguyen Dinh Chien. Houston: Asia Society - The Museum of Fine Arts.

Vickery, M. 1985. The Reign of Sūryavarman I and Royal Factionalism at Angkor. Journal of Southeast Asian Studies 16 (2): 226-244.

Vickery, M. 1998. Society, Economics, and Politics in Pre-Angkor Cambodia: The 7th-8th Centuries. Tokyo: Centre for East Asian Cultural Studies for UNESCO.

Vickery, M. 2003-2004. Funan Reviewed: Deconstructing the Ancients. BEFEO (90-91): 101-143.

Vigasin, A. A., and Samozvantsev, A. M. 1984. 'Arthaśāstra': Problems of Social Structure and Law. Moscow: Nauka. Original in Russian (Вигасин А. А., Самозванцев А. М. Артхашастра: Проблемы сощиальной структуры и права. М.: Наука).

Vogel, J. Ph. 1918. The Yūpa Inscriptions of king Mūlavarman, from Koetei (East Borneo). BTLV 74: 167-232.

Vogel, J. Ph. 1925. The Earliest Sanskrit Inscriptions of Java. Publicaties van den Oudheidkundigen Dienst in Nederlandsch-Indië 15-35. Batavia.

Wheatley, P. 1983. Nāgara and Commandery: Origins of the Southeast Asian Urban Traditions. Research Paper Nos. 207-208. Chicago: University of Chicago, Department of Geography.

Wisseman Ch. J. 1990. Trade and State Formation in the Malay Peninsula and Sumatra, 300 B.C. - A.D. 700. In Kathirithamby-Wells, J., and Villiers, J. (eds.), The Southeast Asian Port and Polity: Rise and Demise (pp. 39-60). Singapore: Singapore University Press, National University of Singapore.

Wisseman Ch. J. 1995. State Formation in Early Maritime Southeast Asia: A Consideration of the Theories and the Data. BTLV 151 (2): 235-288.

Wolters, O. W. 1982. History, Culture, and Region in Southeast Asian Perspectives. Singapore: Institute of Southeast Asian Studies.

Wisseman Ch. J. 1999. History, Culture, and Region in Southeast Asian Perspectives: Revised Edition. New York: Cornell University, Southeast Asia Program; Singapore: Institute of Southeast Asian Studies.

Yung, P. 2000. Angkor: The Khmers in Ancient Chinese Annals. Oxford: Oxford University Press.

Zakharov, A. O. 2010. A Note on the Date of the Vo-canh Stele. South East Asian Review 35: 17-21.

Zakharov, A. O. 2015. Devānīka's Inscription from Văt Luong Kău near Vat Phou in Laos K. 365: first English translation. South East Asian Review 40: 1-23. 